\section{Improvement of the physiologic characters, grain yield and quality of soybean induced by magnetic water and methanol}

\author{
Aref Fatehi, Babak Pasari*, Asad Rokhzadi \\ Department of Agronomy and Plant Breeding, Sanandaj branch, Islamic Azad University, Sanandaj, \\ Iran \\ *Corresponding author, E-mail: bpasary@yahoo.com
}

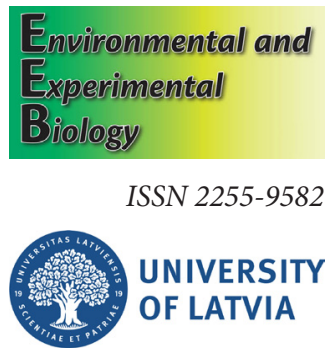

\begin{abstract}
This experiment was performed to improve the physiologic characters, grain yield and quality of soybean, by application of magnetic water and methanol in the research field at the Agriculture Faculty, Islamic Azad University-Sanandaj branch, Iran, during two consecutive years $(2016$ - 2017). The experiment was designed as a split plot. Different intensities of magnetic water (control, 4, 8, 12 mT) were used in the main plot and foliar application of methanol concentrations (control, 10, 20 and 30\% v/v) in sub-plots. Chlorophyll content, leaf relative water content, plant height, grain number per plant, grain yield, oil and protein content were significantly higher in treatments with magnetic water and methanol spraying. Grain yield, oil and protein content were traits increased by magnetic irrigation with 12 and $8 \mathrm{mT}$ intensities, compared to the control, by $72.23,5.32$ and $10.08 \%$, respectively. Methanol foliar application at $20 \%$ concentration increased grain yield, oil and protein content by 19.04, 3.91 and 5.25\%, respectively. The interaction effect of year $\times$ magnetic water was significant for oil and protein content at $5 \%$ probability. The interaction effect of year $\times$ methanol was also significant for plant height, grain yield, and oil and protein content at $1 \%$ probability. The superiority of these traits was evident in the second year under the influence of magnetic water at $8 \mathrm{mT}$ and $20 \%$ methanol. Interaction effects of magnetic water $\times$ methanol indicated that maximum oil content was achieved at $8 \mathrm{mT}$ magnetic water and $20 \%$ methanol treatment.
\end{abstract}

Key words: chlorophyll, grain, growth, irrigation, magnetic water, methanol, relative water content, soybean. Abbreviations: DW, dry weight; FW, fresh weight; RWC, relative water content; SW, saturation weight.

\section{Introduction}

Soybean (Glycine max L.) is known as a valuable plant for oil, protein and meal production in the world. Since the yield gap of soybean, the difference between actual yield and potential yield, is high in Iran $\left(2.44 \mathrm{t} \mathrm{ha}^{-1}\right)$ and other countries, studies on ways to improve the yield and reduce the gap yield of this crop have been targeted (Nehbandani 2020).

In recent years, the application of magnetic fields on irrigation water as a promising and environmentally friendly method to increase crop yields in sustainable agriculture has attracted much attention (Bilalis et al. 2013; Efthimiadou et al. 2014; Teixeira da Silva, Dobránszki 2014; Đukić et al. 2017). Magnetizing can change some of the physical and chemical properties of water, like causing lower electrical conductivity and total dissolved solid content (Ashraf 2014), improved filtration properties, raised dissolving properties (Gora et al. 2018), decreased electrical conductivity, $\mathrm{pH}$ and $\mathrm{Cl}$ anion concentration of water (Hozayn et al.2016). These changes can improve the quality of irrigation water and also plant growth and yield (Eşitken, Turan 2004; Efthimiadou et al. 2014; Elshokali, Abdelbagi
2014; Teixeira da Silva, Dobránszki 2014; Alderfasi et al. 2016; Surendran et al. 2016; Đukić et al. 2017; Babaloo et al. 2018). Furthermore, application of magnetized water increases the leaching of salts downwards in the soil profile, increases fertilizer use efficiency, and reduces the soil $\mathrm{pH}$ and electrical conductivity (Abd-Elrahman, Shalaby 2017). Also, nutrient mobility in the soil profile is improved and the extraction and uptake of phosphorus, potash, nitrogen and iron by plants is increased, thereby increasing the efficiency of applied fertilizers (Gora et al. 2018). Other effects are higher uptake and accumulation of mineral elements into plant, improved seed germination, growth rate and vigour of seedlings (Isaac et al. 2011; Rezaiiasl et al. 2012; Asadi Samani et al. 2013; Alderfasi et al. 2016; Đukić et al. 2017; Babaloo et al.2018), and higher growth and crop yield (Eşitken, Turan 2004; Rezaiiasl et al. 2012; Bilalis et al. 2013; Hozayn et al. 2016). Magnetic water improves plant yield and water use efficiency, at the same time providing the possibility of irrigation with lower quality water, such as saline water, hard water, recycled water and wastewater, which can be necessary in areas such as Iran, which suffer from insufficient water or low water quality (Maheshwari, Grewal. 2009; Alderfasi et al. 2016; Surendran et al. 2016). 
Magnetic water provides more adhesion to soil particles, resulting in reduced water loss due to leaching, hence water retention and accessibility in the soil profile increases after irrigation. This can increase the motility and absorption of nutrients in the root zone and thus increase crop production (Surendran et al. 2016).

Increased growth and yield of crops depend on the availability of inputs, including of water and carbon dioxide in photosynthesis. Numerous studies have shown a positive effect of increasing the concentration of carbon dioxide around plants on increasing growth, especially in $\mathrm{C}_{3}$ plants (Thompson et al. 2017; Liu et al. 2019; MorenoDelafuente et al. 2020; Singh et al. 2020). Due to the need of plants for carbon dioxide, methanol foliar application is recommended as a fertiliser; methylotrophic bacteria on leaf surfaces can convert methanol into water and $\mathrm{CO}_{2}$ (Galbally, Kirstine 2002) and thus increases photosynthesis, growth and yield of plants (Jafari Paskiabi et al. 2011).

Studies have shown the positive effects of methanol foliar application on plant growth and development, such as prevention of photorespiration in $\mathrm{C}_{3}$ plants (Bai et al. 2014), increase of metabolic heat rate and carbon conversion efficiency (Hemming et al. 1995), improved plant resistance to biotic and abiotic stresses (Dorokhov et al. 2018), reduced water stress damage (Bayat et al. 2012; Hossinzadeh et al.2012), improved plant protection against insect pests (Dixit et al. 2013), increased crop yield (Li et al. 1995; Mirakhori et al. 2009; Jafari Paskiabi et al. 2011; Bayat et al. 2012; Hossinzadeh et al. 2012), and higher seed oil and protein content (Bayat et al. 2012).

Therefore, the aim of this study was develop methods for increasing grain yield and improving grain quality traits, such as oil and protein content, by increasing the magnetic water capacity to absorb mineral elements from the soil. Also, methanol was used to increase the concentration of $\mathrm{CO}_{2}$ around the plant canopy to increase plant photosynthetic activity. It was hypothesized that the treatments would leads to increased quantitative and qualitative yield of the soybean plant.

\section{Materials and methods}

This experiment was carried out to improve the physiologic characters, grain yield and quality of soybean by application of magnetic water and methanol in the research field of the Agriculture Faculty, Islamic Azad University-Sanandaj branch. The research field was located in northwest Iran $\left(35^{\circ} 10^{\prime} 23^{\prime \prime} \mathrm{N}, 46^{\circ} 59^{\prime} 23^{\prime \prime} \mathrm{E}\right.$ and $1312 \mathrm{~m}$ above sea level). In order to avoid possible effects of treatment in the first year in the experimental field, in the second year, another field was selected at a $330 \mathrm{~m}$ distance from the first year field. The region has semi-dry and cold climate. Some of the meteorological characteristics of the experimental farm during the two-year period were obtained from the Sanandaj Meteorological Station (Table 1).

The experiment was carried out as split plots in a randomized complete block design with three replications during two consecutive years (2016 and 2017). Different intensities of magnetic water (control, 4, 8, $12 \mathrm{mT}$ ) were used in the main plot and foliar application of methanol concentrations in distilled water (control, 10, 20 and 30\% $\mathrm{v} / \mathrm{v}$ ) in the sub-plots.

In the fall of the year before the experiment, deep plowing was carried out on the experimental farm. In spring, after re-plowing and discing, soil samples were taken in different part of the field following a spatial pattern of the letter "W"

Table 1. Meteorological parameters in Sanandaj synoptic meteorological station during two consecutive years

\begin{tabular}{|c|c|c|c|c|c|c|c|c|}
\hline Month & Year & $\begin{array}{c}\text { Monthly } \\
\text { evaporation } \\
(\mathrm{mm})\end{array}$ & $\begin{array}{c}\text { Monthly } \\
\text { sunshine } \\
\text { duration (h) }\end{array}$ & $\begin{array}{c}\text { Monthly } \\
\text { rainfall } \\
(\mathrm{mm})\end{array}$ & $\begin{array}{c}\text { Maximum } \\
\text { relative } \\
\text { humidity (\%) }\end{array}$ & $\begin{array}{c}\text { Minimum } \\
\text { relative } \\
\text { humidity (\%) }\end{array}$ & $\begin{array}{c}\text { Maximum } \\
\text { temperature } \\
\left({ }^{\circ} \mathrm{C}\right)\end{array}$ & $\begin{array}{c}\text { Minimum } \\
\text { temperature } \\
\left({ }^{\circ} \mathrm{C}\right)\end{array}$ \\
\hline \multirow[t]{2}{*}{ April } & 2016 & 134.4 & 235.8 & 43.35 & 94 & 15 & 20.1 & 5.2 \\
\hline & 2017 & 151.3 & 226.8 & 56.57 & 94 & 10 & 18.9 & 6.4 \\
\hline \multirow[t]{2}{*}{ May } & 2016 & 207.4 & 308.7 & 22.86 & 91 & 4 & 22.3 & 10.8 \\
\hline & 2017 & 228.5 & 331.4 & 24.15 & 92 & 2 & 22.6 & 13.0 \\
\hline \multirow[t]{2}{*}{ June } & 2016 & 331.4 & 335.4 & 0.22 & 71 & 7 & 29.9 & 19.0 \\
\hline & 2017 & 330.2 & 389.4 & 0 & 65 & 4 & 30.7 & 17.9 \\
\hline \multirow[t]{2}{*}{ July } & 2016 & 377.3 & 379.1 & 0 & 50 & 6 & 32.8 & 26.5 \\
\hline & 2017 & 392.5 & 342.9 & 0 & 51 & 5 & 31.6 & 27.0 \\
\hline \multirow[t]{2}{*}{ August } & 2016 & 368.2 & 365.2 & 0 & 62 & 3 & 31.7 & 27.1 \\
\hline & 2017 & 345.0 & 357.2 & 0.01 & 49 & 6 & 32.2 & 26.5 \\
\hline \multirow[t]{2}{*}{ September } & 2016 & 283.6 & 323.7 & 0 & 71 & 5 & 25.3 & 17.1 \\
\hline & 2017 & 251.1 & 307.1 & 0 & 59 & 4 & 27.2 & 17.8 \\
\hline \multirow[t]{2}{*}{ October } & 2016 & 168.1 & 291.3 & 4.20 & 93 & 5 & 17.9 & 12.0 \\
\hline & 2017 & 175.7 & 280.1 & 0.24 & 68 & 7 & 21.2 & 11.2 \\
\hline \multirow[t]{2}{*}{ November } & 2016 & 74.8 & 242.9 & 9.43 & 95 & 10 & 14.4 & 0 \\
\hline & 2017 & 42.2 & 166.7 & 39.77 & 94 & 17 & 15.0 & 6.9 \\
\hline
\end{tabular}


to determine the physical and chemical properties of the soil (Table 2). The recommended fertilizers were applied based on soil tests: urea $\left(50 \mathrm{~kg} \mathrm{ha}^{-1}\right)$, triple superphosphate $\left(75 \mathrm{~kg} \mathrm{ha}^{-1}\right)$ and potassium sulfate $\left(100 \mathrm{~kg} \mathrm{ha}^{-1}\right)$ prior to planting and mixed with soil. In the second year fertilizer application was: 70,200 and $90 \mathrm{~kg} \mathrm{ha}^{-1}$, respectively. Supplementary operations, including re-discing, land leveling and planting furrows, were performed.

In each experimental plot, four rows of sowing lines with a length of $4 \mathrm{~m}$ and at intervals of $50 \mathrm{~cm}$ were used. Soybean seeds were inoculated with nitrogen fixation bacteria (Rhizobium japonicum) before planting and after drying in the shade, planted $7 \mathrm{~cm}$ apart at a depth of $5 \mathrm{~cm}$ in late May.

The soybean cultivar used was Katoul (DPX3589), originated in the United States. This cultivar belongs to maturity group 5 with relatively resistant to charcoal rot disease and soybean cyst nematode and is suitable for mechanized harvesting due to formation of pods at higher nodes of the stem and also due to uniformity of pod ripening.

The drip-strip method was used for irrigation. In order to apply a magnetic field to the irrigation water (from 30 days after planting until the end of the growing season), to maintain the same water pressure during the irrigation process, the water was stored in a storage tank that was constantly charged. A magnetic field induction device with different intensities, which was calibrated with a teslameter device (Leybold Didactic, Germany) was placed at the water outlet. Before the water entered the field, a water measurement device was placed in experimental plots to ensure that the same amount of water was received. The irrigation cycle was five days at the beginning of the season and decreased to four and three days with the onset of the summer season.

For the methanol spray treatments, different concentrations were obtained by diluting methanol with distilled water. For each liter of solution used, $2 \mathrm{~g}$ of glycine was added (Nonomura, Benson 1992). Methanol spraying was performed three times $(60,75$ and 90 days after planting) using a $20 \mathrm{~L}$ hand sprayer. In order to apply the same volume of spray solution, first the control plots were sprayed with distilled water and the volume of solution used in each plot was calculated and this volume was used accordingly in the other treatments in the cool hours of the day. Foliar spraying was continued until the emergence and fall of the solution droplets from leaves. Weed control was carried out manually during the growing season. No pests and disease were observed and harvest operations took place in early November.

The studied plant characteristics in the experiment were: relative water content (RWC), chlorophyll content, plant height, seed number per plant, grain yield, seed oil and protein content. To measure the RWC and chlorophyll content, $48 \mathrm{~h}$ after the second foliar application, five plants per plot were selected randomly. The chlorophyll content was measured as SPAD number by a chlorophyll meter (SPAD 502, Minolta Co, Japan) from the upper leaves of the plant. For measurement of RWC, pieces of upper leaves were separated and immediately placed in an ice tank. In the laboratory, the fresh weight (FW) of the leaf pieces was measured, then all leaf pieces were placed in distilled water at $4{ }^{\circ} \mathrm{C}$ for $24 \mathrm{~h}$ in a refrigerator. After that, leaf pieces saturation weight (SW) was measured and then they were placed in oven at $70^{\circ} \mathrm{C}$ for $48 \mathrm{~h}$, and subsequently their dry weight (DW) was measured. RWC was calculated by the following formula (Ritchie et al. 1990):

$$
\mathrm{RWC}=\mathrm{FW}-\mathrm{DW} / \mathrm{SW}-\mathrm{DW} \times 100 .
$$

In the ripening stage, mean plant height was obtained from five selected plants, from the crown to the tip of the plant. Also the mean number of grain per plant was estimated from five plants randomly selected in each plot. The plants of the middle rows in each plot were harvested and grain yield was obtained after separating the grain and cleaning them completely from plant remains. The grain oil and protein percentages were obtained by Soxhlet and

Table 2. Physico-chemical characteristics of soil in the site of study during two consecutive years

\begin{tabular}{|c|c|c|c|c|}
\hline \multirow[t]{3}{*}{ Parameter } & \multicolumn{4}{|c|}{ Soil depth (cm) } \\
\hline & \multicolumn{2}{|c|}{0 to 30} & \multicolumn{2}{|c|}{30 to 60} \\
\hline & 2016 & 2017 & 2016 & 2017 \\
\hline $\mathrm{K}\left(\mathrm{mg} \mathrm{kg}^{-1}\right)$ & 234 & 180 & 205 & 110 \\
\hline $\mathrm{P}\left(\mathrm{mg} \mathrm{kg}^{-1}\right)$ & 14.0 & 9.5 & 10.9 & 7.3 \\
\hline Total nitrogen (\%) & 0.11 & 0.08 & 0.08 & 0.06 \\
\hline Organic matter $(\%)$ & 1.13 & 0.83 & 0.83 & 0.58 \\
\hline Total neutralizing value (\%) & 4.5 & 10.0 & 7.3 & 13.8 \\
\hline $\mathrm{pH}$ & 7.69 & 7.99 & 8.01 & 8.03 \\
\hline Electrical conductivity $\left(\mathrm{dS} \mathrm{m}^{-1}\right)$ & 0.489 & 0.501 & 0.535 & 0.542 \\
\hline Soil texture & Loam & Sandy clay loam & Clay loam & Loam \\
\hline Silt (\%) & 34 & 23 & 28 & 29 \\
\hline Sand (\%) & 34 & 56 & 40 & 46 \\
\hline Clay (\%) & 32 & 21 & 32 & 25 \\
\hline
\end{tabular}


Kjeldahl method, respectively.

After testing for normality of data distribution and homogeneity of variance, significant differencecs were tested by Duncan's multiple range tests at the 0.05 , using SAS9.1.

\section{Results}

\section{Relative water content}

The highest RWC occurred in $12 \mathrm{mT}$ magnetic water and $20 \%$ methanol treatments (Table 3). The effect of RWC was significant for magnetic water and methanol spraying at

Table 3. Effect of magnetic water and methanol treatment on soybean traits. Means with different letters are statistically significantly different $(p<0.05)$ for the respective parameter

\begin{tabular}{|c|c|c|c|c|c|}
\hline \multirow{2}{*}{$\begin{array}{l}\text { Methanol spray (\% } \\
\text { v/v) }\end{array}$} & \multicolumn{5}{|c|}{ Magnetic water (mT) } \\
\hline & 0 & 4 & 8 & 12 & Mean \\
\hline \multicolumn{6}{|c|}{ RWC (\%) } \\
\hline Distilled water (0) & $46.68 \pm 2.97 \mathrm{ef}$ & $52.79 \pm 2.78 \mathrm{de}$ & $59.26 \pm 1.93 \mathrm{bc}$ & $54.22 \pm 1.38 \mathrm{~cd}$ & $53.23 \mathrm{c}$ \\
\hline 10 & $49.75 \pm 4.10 \mathrm{def}$ & $57.71 \pm 1.78 \mathrm{bc}$ & $62.96 \pm 2.67 \mathrm{ab}$ & $57.03 \pm 2.56 \mathrm{bc}$ & $56.86 \mathrm{~b}$ \\
\hline 20 & $54.34 \pm 3.04 \mathrm{~cd}$ & $61.42 \pm 3.89 \mathrm{ab}$ & $66.42 \pm 1.53 \mathrm{a}$ & $66.52 \pm 3.54 \mathrm{a}$ & $62.17 \mathrm{a}$ \\
\hline 30 & $45.50 \pm 2.80 \mathrm{f}$ & $53.42 \pm 3.20 \mathrm{~cd}$ & $58.88 \pm 1.82 \mathrm{bc}$ & $48.79 \pm 2.67 \mathrm{def}$ & $51.64 \mathrm{c}$ \\
\hline Mean & $49.06 \mathrm{c}$ & $56.33 \mathrm{~b}$ & $61.88 \mathrm{a}$ & $54.64 \mathrm{~b}$ & \\
\hline \multicolumn{6}{|c|}{ Chlorophyll content (SPAD units) } \\
\hline Distilled water (0) & $33.82 \pm 1.05 \mathrm{f}$ & $40.38 \pm 0.66 \mathrm{~d}$ & $42.33 \pm 0.66 \mathrm{bcd}$ & $42.13 \pm 0.58 \mathrm{bcd}$ & $39.66 \mathrm{c}$ \\
\hline 10 & $33.26 \pm 0.99 \mathrm{e}$ & $43.05 \pm 0.38 \mathrm{bc}$ & $43.31 \pm 0.42 \mathrm{bc}$ & $43.83 \pm 1.21 \mathrm{~b}$ & $41.86 \mathrm{~b}$ \\
\hline 20 & $38.18 \pm 0.68 \mathrm{e}$ & $44.16 \pm 0.73 \mathrm{~b}$ & $46.15 \pm 0.48 \mathrm{a}$ & $47.58 \pm 0.64 \mathrm{a}$ & $44.02 \mathrm{a}$ \\
\hline 30 & $35.23 \pm 1.09 \mathrm{f}$ & $41.76 \pm 0.84 \mathrm{~cd}$ & $41.31 \pm 0.38 \mathrm{~cd}$ & $41.30 \pm 0.64 \mathrm{~cd}$ & $39.90 \mathrm{c}$ \\
\hline Mean & $36.12 \mathrm{c}$ & $42.34 \mathrm{~b}$ & $43.27 \mathrm{a}$ & $43.71 \mathrm{a}$ & \\
\hline \multicolumn{6}{|c|}{ Plant height $(\mathrm{cm})$} \\
\hline Distilled water (0) & $97.85 \pm 1.56 \mathrm{~g}$ & $128.03 \pm 8.84 \mathrm{de}$ & $127.75 \pm 5.84 \mathrm{de}$ & $131.87 \pm 5.93 \mathrm{cde}$ & $121.37 \mathrm{~b}$ \\
\hline 10 & $104.98 \pm 1.60 \mathrm{fg}$ & $136.37 \pm 9.72$ bcde & $137.95 \pm 6.28 \mathrm{abcd}$ & $145.12 \pm 8.21 \mathrm{ab}$ & $131.10 \mathrm{~b}$ \\
\hline 20 & $109.47 \pm 1.66 \mathrm{f}$ & $140.57 \pm 7.06 \mathrm{abc}$ & $143.80 \pm 10.90 \mathrm{ab}$ & $147.53 \pm 7.14 \mathrm{a}$ & $135.33 \mathrm{a}$ \\
\hline 30 & $94.82 \pm 3.68 \mathrm{~g}$ & $130.48 \pm 8.78 \mathrm{cde}$ & $125.43 \pm 6.44 \mathrm{e}$ & $136.10 \pm 4.50$ bcde & $121.70 \mathrm{~b}$ \\
\hline Mean & $101.77 \mathrm{c}$ & $133.86 \mathrm{~b}$ & $133.72 \mathrm{~b}$ & $140.15 \mathrm{a}$ & \\
\hline \multicolumn{6}{|c|}{ Grain number per plant } \\
\hline Distilled water (0) & $78.75 \pm 5.28 \mathrm{~g}$ & $114.80 \pm 12.40 \mathrm{bcde}$ & $112.20 \pm 6.66 \mathrm{cdef}$ & $105.83 \pm 9.80 \mathrm{cdef}$ & $102.89 \mathrm{c}$ \\
\hline 10 & $85.92 \pm 3.45 \mathrm{fg}$ & $124.57 \pm 7.01 \mathrm{bcd}$ & $128.47 \pm 8.94 \mathrm{abc}$ & $127.73 \pm 9.99 \mathrm{abcd}$ & $116.67 \mathrm{~b}$ \\
\hline 20 & $101.12 \pm 6.63 \mathrm{defg}$ & $126.70 \pm 10.60 \mathrm{abcd}$ & $136.38 \pm 9.40 \mathrm{ab}$ & $152.62 \pm 7.51 \mathrm{a}$ & $129.20 \mathrm{a}$ \\
\hline 30 & $94.22 \pm 640$ efg & $101.08 \pm 3.59$ befg & $106.15 \pm 8.74 \mathrm{cdef}$ & $129.77 \pm 9.45 \mathrm{abc}$ & $107.80 \mathrm{bc}$ \\
\hline Mean & $90.00 \mathrm{c}$ & $116.78 \mathrm{~b}$ & $120.80 \mathrm{ab}$ & $128.98 \mathrm{a}$ & \\
\hline \multicolumn{6}{|c|}{ Grain yield per plant $(\mathrm{g})$} \\
\hline Distilled water (0) & $9.11 \pm 0.82 \mathrm{e}$ & $14.23 \pm 1.64 \mathrm{bcd}$ & $13.63 \pm 2.12 \mathrm{cde}$ & $14.30 \pm 1.03 \mathrm{bcd}$ & $12.81 \mathrm{~b}$ \\
\hline 10 & $9.89 \pm 0.48 \mathrm{de}$ & $12.49 \pm 0.82 \mathrm{cde}$ & $15.86 \pm 2.32 \mathrm{abc}$ & $15.76 \pm 1.56 \mathrm{abc}$ & $13.50 \mathrm{ab}$ \\
\hline 20 & $9.30 \pm 0.80 \mathrm{e}$ & $13.71 \pm 1.91 \mathrm{cde}$ & $18.47 \pm 1.75 \mathrm{ab}$ & $19.53 \pm 2.74 \mathrm{a}$ & $15.25 \mathrm{a}$ \\
\hline 30 & $9.29 \pm 1.62 \mathrm{e}$ & $14.31 \pm 0.97 \mathrm{bcd}$ & $16.00 \pm 2.27 \mathrm{abc}$ & $15.17 \pm 0.90 \mathrm{abc}$ & $13.69 \mathrm{ab}$ \\
\hline Mean & $9.40 \mathrm{c}$ & $13.68 \mathrm{~b}$ & $15.99 \mathrm{a}$ & $16.19 \mathrm{a}$ & \\
\hline \multicolumn{6}{|c|}{ Oil (\%) } \\
\hline Distilled water (0) & $16.05 \pm 0.26 \mathrm{i}$ & $18.53 \pm 0.30 \mathrm{~g}$ & $20.10 \pm 0.27 \mathrm{e}$ & $18.73 \pm 0.70 \mathrm{~g}$ & $18.35 \mathrm{~d}$ \\
\hline 10 & $17.30 \pm 0.26 \mathrm{~h}$ & $19.81 \pm 0.23$ ef & $23.80 \pm 0.28 b$ & $20.96 \pm 0.60 \mathrm{~d}$ & $20.47 \mathrm{~b}$ \\
\hline 20 & $18.78 \pm 0.21 \mathrm{~g}$ & $21.93 \pm 0.32 c$ & $24.70 \pm 0.22 \mathrm{a}$ & $23.65 \pm 0.66 b$ & $22.26 \mathrm{a}$ \\
\hline 30 & $16.58 \pm 0.34 \mathrm{hi}$ & $19.11 \pm 0.45 \mathrm{fg}$ & $21.38 \pm 0.19 \mathrm{~cd}$ & $18.35 \pm 0.43 \mathrm{~g}$ & $18.85 \mathrm{c}$ \\
\hline Mean & $17.17 \mathrm{~d}$ & $19.85 \mathrm{c}$ & $22.49 \mathrm{a}$ & $20.42 \mathrm{~b}$ & \\
\hline \multicolumn{6}{|c|}{ Protein (\%) } \\
\hline Distilled water $(0)$ & $31.16 \pm 0.33 \mathrm{~h}$ & $35.90 \pm 1.02$ ef & $40.31 \pm 0.22 \mathrm{~cd}$ & $36.25 \pm 1.27$ ef & $35.90 \mathrm{~d}$ \\
\hline 10 & $32.96 \pm 0.22 \mathrm{~g}$ & $39.37 \pm 1.26 \mathrm{~d}$ & $43.03 \pm 0.70 b$ & $40.30 \pm 1.49 \mathrm{~cd}$ & $38.91 \mathrm{~b}$ \\
\hline 20 & $34.65 \pm 0.25 \mathrm{f}$ & $41.63 \pm 1.15 b c$ & $46.61 \pm 0.89 a$ & $41.72 \pm 1.77 \mathrm{bc}$ & $41.15 \mathrm{a}$ \\
\hline 30 & $32.13 \pm 0.51 \mathrm{gh}$ & $36.26 \pm 0.61$ ef & $41.23 \pm 0.29 c$ & $37.55 \pm 0.63 \mathrm{e}$ & $36.79 \mathrm{c}$ \\
\hline Mean & $32.72 \mathrm{c}$ & $38.29 \mathrm{~b}$ & $42.80 \mathrm{a}$ & $38.95 \mathrm{~b}$ & \\
\hline
\end{tabular}


the $1 \%$ level (Table 4). As shown in Table 3, the application of magnetic water at different intensities increased the relative water content of leaves, compared to the control. The maximum value was obtained at $8 \mathrm{mT}$, with a $12.82 \%$ improvement over the control. In this experiment, methanol application also increased the RWC of leaves, such that its value increased by $8.94 \%$ more than the control in the $20 \%$ concentration. However, in higher concentrations of methanol, RWC decreased compared with the control (Table 3).

\section{Chlorophyll content}

SPAD chlorophyll meter was used as an appropriate and non-destructive tool for measuring chlorophyll content in the plants. The application of $12 \mathrm{mT}$ magnetic water and $20 \%$ methanol increased the SPAD reading (Table 3 ). Significant differences of SPAD readings at the $1 \%$ level occurred between magnetic water and methanol spraying treatments (Table 4). As the intensity of the magnetic water increased, the amount of chlorophyll increased, reaching the maximum value 8 and $12 \mathrm{mT}$, but without significant differences. The application of magnetic water at 4, 8 and $12 \mathrm{mT}$ intensity increased the chlorophyll content by 17.22 , 19.79 and $21.01 \%$, respectively (Table 3 ). The SPAD reading was $10.99 \%$ higher in the $20 \%$ methanol treatment than in the control (Table 4).

\section{Plant height}

The synergistic effects of the treatments on plant height are shown in Table 3. The effect of magnetic water on plant height was significant at the $1 \%$ level. The results of the means comparison showed that the maximum height recorded by $12 \mathrm{mT}$ intensity, 37.7\% more than control (Table 3). Plant height was significantly affected by methanol treatment at a level of $1 \%$, and the interaction between year $\times$ methanol foliar application was also significant. Foliar application of methanol at $20 \%$ concentration increased height by $11.5 \%$.
Maximum plant height was obtained in the $20 \%$ methanol treatment in the second year of the experiment.

\section{Grain number per plant}

Maximum grain number was obtained in the treatment combination with $12 \mathrm{mT}$ magnetic water and $20 \%$ methanol (Table 3 ). The maximum number of grains per plant was obtained in the second year of the experiment. It is possible that the occurrence of suitable climatic conditions in the second year, including higher minimum temperature and total rainfall (Table 2), improved the growth of flowers and pods, and as a result, increased the number of grains in the plant.

Treatment with magnetic water increased the number of grains in the plant, and the maximum number of grains was obtained in the $12 \mathrm{mT}$ treatment, which was $43.31 \%$ higher than in the control. ANOVA and mean comparison tables showed that the $20 \%$ methanol treatment significantly improved grain number (by $25.57 \%$ in comparison with the control).

\section{Grain yield}

The grain yield, as the most important trait, was highest in the combination of $12 \mathrm{mT}$ magnetic water and $20 \%$ methanol treatments (Table 3). Grain yield significantly differed at the $1 \%$ level between magnetic water treatment with an increasing trend with increasing magnetic field intensity. Maximum grain yield was obtained in the $12 \mathrm{mT}$ treatment, although no significant difference was observed with the $8 \mathrm{mT}$ treatment. Magnetic water treatment improved grain yield by 45 to $72 \%$.

The effect of methanol on grain yield was significant, causing 5 to $19 \%$ higher yields in the 10 and $20 \%$ treatments. In this experiment, grain yield per plant was affected by the interaction of methanol $\times$ year and the maximum yield was obtained in the second year and 20\% methanol foliar application.

Table 4. The combined ANOVA analysis of effect of magnetic water and methanol on physiologic and agronomic traits of soybean. *, statistically significant at $p<0.05$; ${ }^{* *}$, statistically significant at $p<0.01$; ns, nonsignificant; $\mathrm{CV}$, coefficient of variation

\begin{tabular}{|c|c|c|c|c|c|c|c|c|}
\hline S.O.V & df & RWC & $\begin{array}{c}\text { Chlorophyll } \\
\text { content }\end{array}$ & Plant height & $\begin{array}{c}\text { Grain } \\
\text { number per } \\
\text { plant }\end{array}$ & $\begin{array}{c}\text { Grain yield } \\
\text { per plant }\end{array}$ & Oil content & $\begin{array}{l}\text { Protein } \\
\text { content }\end{array}$ \\
\hline Year & 1 & $107.51 \mathrm{~ns}$ & $5.70 \mathrm{~ns}$ & $2341.36 \mathrm{~ns}$ & $3642.03 \mathrm{~ns}$ & $0.04 \mathrm{~ns}$ & $0.09 \mathrm{~ns}$ & $84.37^{* *}$ \\
\hline Replicate (year) & 4 & $252.86 \mathrm{~ns}$ & $8.61 \mathrm{~ns}$ & $1504.74 \mathrm{~ns}$ & $154.06 \mathrm{~ns}$ & $10.77 \mathrm{~ns}$ & $1.28 \mathrm{~ns}$ & $15.10 \mathrm{~ns}$ \\
\hline Magnetic water & 3 & $665.48^{* *}$ & $300.69^{* *}$ & $7206.91^{* *}$ & $6836.24^{* *}$ & $238.88^{* *}$ & $115.11^{* *}$ & $413.33^{* *}$ \\
\hline Year $\times$ MW & 3 & $29.33 \mathrm{~ns}$ & $6.59 \mathrm{~ns}$ & $402.29 \mathrm{~ns}$ & $150.78 \mathrm{~ns}$ & $14.81 \mathrm{~ns}$ & $4.26^{*}$ & $15.61 *$ \\
\hline $\mathrm{Ea}$ & 12 & 92.95 & 6.05 & 543.14 & 310.35 & 16.52 & 1.20 & 4.66 \\
\hline Methanol spray & 3 & $523.37^{\star *}$ & $98.58^{\star *}$ & $1162.82^{* *}$ & $3198.26^{* *}$ & $25.42 *$ & $74.96^{* *}$ & $131.71^{* *}$ \\
\hline Year $\times$ MS & 3 & $13.95 \mathrm{~ns}$ & $0.90 \mathrm{~ns}$ & $526.72^{\star *}$ & $1034.1 \mathrm{~ns}$ & $116.45^{\star *}$ & $3.40^{* *}$ & $11.33^{* *}$ \\
\hline $\mathrm{MW} \times \mathrm{MS}$ & 9 & $24.39 \mathrm{~ns}$ & $4.44 \mathrm{~ns}$ & $23.87 \mathrm{~ns}$ & $520.87 \mathrm{~ns}$ & $11.61 \mathrm{~ns}$ & $3.16^{* *}$ & $3.19 \mathrm{~ns}$ \\
\hline Year $\times \mathrm{MW} \times \mathrm{MS}$ & 9 & $21.49 \mathrm{~ns}$ & $2.75 \mathrm{~ns}$ & $84.46 \mathrm{~ns}$ & $221.09 \mathrm{~ns}$ & $5.01 \mathrm{~ns}$ & $0.96 \mathrm{~ns}$ & $3.64 \mathrm{~ns}$ \\
\hline $\mathrm{Eb}$ & 48 & 23.98 & 2.43 & 71.27 & 395.12 & 12.15 & 0.49 & 1.98 \\
\hline $\mathrm{CV}$ & - & 8.74 & 3.77 & 6.62 & 17.41 & 25.22 & 3.51 & 3.69 \\
\hline
\end{tabular}




\section{Grain oil and protein}

Oil content is one of the most important qualitative traits of soybean grain. The oil content was $8.65 \%$ higher in the $8 \mathrm{mT}$ magnetic water and $20 \%$ methanol treatment, compared to the control (Table 3 ). The effect of magnetic water on grain oil content was significant at $1 \%$ probability. Maximum oil content was achieved in the $8 \mathrm{mT}$ treatment, which was $5.32 \%$ higher than in the control. Oil was significantly affected by the interaction of year $\times$ magnetic water at the $5 \%$ level, and was highest in the $8 \mathrm{mT}$ treatment in both years of the study. ANOVA showed that oil content was affected by methanol spraying, and by year $\times$ methanol and magnetic water $\times$ methanol interactions, at $1 \%$ probability. Foliar application of $20 \%$ methanol resulted in a $3.91 \%$ increase in oil content, compared to the control. The maximum oil content was obtained in the $20 \%$ methanol treatment in both years.

Protein content is the second most important qualitative characters of soybean grain. Maximum protein content was obtained in the $8 \mathrm{mT}$ magnetic water and $20 \%$ methanol foliar application (Table 3). Furthermore this trait was affected by the year and the magnetic water at the $1 \%$ level and influenced by their interaction at $5 \%$ level. The maximum protein percentage was obtained by 8 $\mathrm{mT}$ treatment, which increased by $10.08 \%$ compared with the control. The results of the interaction showed that the maximum amount of protein was obtained in the second year of the experiment and by $8 \mathrm{mT}$ magnetic water.

As mentioned earlier, it is likely that favorable climatic conditions in the second year of the experiment will improve the absorption of nutrients involved in protein synthesis under the influence of magnetic water. In this study, the effect of methanol foliar application, as well as the interaction between year $\times$ methanol foliar applications on protein percent was significant at $1 \%$ probability. The application of methanol increased the protein content of the seeds and its maximum value was observed in $20 \%$ volumetric treatment, which was $5.25 \%$ higher than the control. The results of the interaction also indicated an increase in protein content in the second year of the experiment and in the $20 \%$ methanol.

\section{Discussion}

In the present study, dual application of magnetized water and methanol increased RWC, chlorophyll content, plant height, grain number per plant and, also grain yield and quality parameters like seed oil and protein of soybean plants in field conditions.

Magnetic water can improve the soil water holding capacity and water absorption rate by the plant and also regulates the function of the plant stomata (Anand et al. 2012; Bilalis et al. 2013; El Sayed 2014; Sadeghipour 2016; Yusuf, Ogunlela 2017). It can facilitate the movement of water molecules through cell walls, causing an increase in the water content of the leaf cells (Gora et al. 2018).
After methanol spraying, methylotrophic bacteria on leaf surfaces can convert methanol into water and $\mathrm{CO}_{2}$ (Galbally, Kirstine 2002) and these two products are directly absorbed by leaf cells through stomata, increasing the amount of cellular water and concentration of carbon dioxide, increasing the amount of photosynthetic pigments, leaf fresh weight and also soybean yield (Radha et al. 2009).

As nitrogen is one of the main elements in the structure of chlorophyll and because the magnetic water can increase the activity of nitrogen fixation bacteria symbiosis on plant roots leading to increased uptake, magnetic water treatment can also cause increased content of chlorophyll in leaf tissues (Aliverdi et al. 2015). Accumulation of photosynthetic pigments increases photosynthesis and also improves plant water status, resulting in growth stimulation, seen as increased cell length and plant height (Babaloo et al.2018). Improvement of cell elongation by the magnetic field was related to the osmotic pressure of the cell sap in the epidermal cells of plants (Negishi et al. 1999). In addition, stimulation of photosynthesis, transpiration, stomatal conductance, growth, root and shoot dry weight by a magnetic field has been associated with improved macronutrient (N, P, K, Ca and $\mathrm{Mg}$ ) accumulation (Bilalis et al. 2013), and also mobility and uptake of micronutrients (Fe, $\mathrm{Zn}$ and $\mathrm{Mn}$ ) (Alderfasi et al. 2016).

Methanol application can affect leaf area index, crop growth rate and increase leaf area of plants (Mirakhori et al. 2009). It seems that the increase in the RWC and chlorophyll content along with the increase in plant height under the cumulative influence of magnetic water and methanol, increased light absorption, photosynthesis and, as a result, the transfer of photosynthetic products to flowers and the formation of more grains. A high positive correlation between soybean grain yield and relative water content and chlorophyll content, as affected by methanol spray, has been previously shown (Bayat et al. 2012). Magnetic water can promote the germination percentage (Alderfasi et al.2016; Đukić et al. 2017). In addition, enzyme activities of $a$-amylase, dehydrogenase, and protease are higher in germinated seeds, (Asadi Samani et al. 2013). Acceleratied germination and increased seedling growth under the influence of a magnetic field can further increase the absorption of water and nutrients by increasing root growth, resulting in increased leaf number, leaf area and plant photosynthesis (Rezaiiasl et al. 2012; Alderfasi et al. 2016; Surendran et al. 2016). A large plant canopy cover over soil can reduce the number of weeds and also promote nutrient and water use efficiency (El Sayed 2014).

The promotion of soybean grain yield by magnetic water may be amplified by accelerating the activity of nitrogen bacteria fixation on the root surface or nodule number per plant that encourage nitrogen fixation and consequently improve yield (Aliverdi et al. 2015). On the other hand, the exposure of water in the magnetic field increases its temperature by 0.4 to $0.8^{\circ} \mathrm{C}$, which affects the rate of water evaporation (Shalatonin 2017). Probably this can increase 
the solubility of the elements in the soil after irrigation and thus by increasing the transpiration flow, facilitate nutrient absorption.

Increased yield of different plants by methanol application has been attributed to several reasons, such as extended leaf longevity and improvement of photosynthesis rate (Feibert et al. 1995), higher activity of fructose 1,6-bisphosphate enzyme, which is effective in photosynthesis (Nonomura, Benson 1997), promotion of leaf gas exchange (Faver, Gerik 1996), increased rate of $\mathrm{CO}_{2}$ assimilation, transpiration, leaf conductivity, amplification of nitrate reductase and alkaline phosphatase activity (Zbieć et al. 2003), finally leading to higher leaf area index, crop growth rate and yield attributes (Mirakhori et al. 2009).

Increasing solubility and absorption of essential plant nutrients by magnetic water, together with increasing availability and fixation of $\mathrm{CO}_{2}$ in photosynthesis through foliar application of methanol, may have increased the oil and protein content of grains. The increase in soybean oil and protein content has been confirmed by the application of iron and manganese (Kobraee, Shamsi 2015). Magnetic water can cause a significant increase in $\mathrm{Mn}$ and $\mathrm{Cu}$ micronutrients contents in plants, resulting in increased seed oil (14.29\%) and unsaturated fatty acids contents (34.1\%), and oil yield (58.51\%) (Hozayn et al. 2016). Similarly, the number of protein bands was increased by magnetized water in flax, wheat, lentil and chickpea (Hozayn et al. 2011). In another study, it was found that magnetic water treatment could lead to higher content of carbohydrates and protein of broad bean by 13.68 and $19.69 \%$, respectively (El Sayed 2014). The reason for this increase was due to increased amounts of stimulating hormones, such as indole-3-acetic acid, gibberellic acid and cytokinins. It was also mentioned that magnetic water can increase potassium, calcium and phosphorous content in all parts (roots, stems, leaves and seeds) of broad bean (El Sayed 2014).

\section{Conclusion}

Irrigation of plants with magnetized water at intensities of 8 and $12 \mathrm{mT}$ increased the relative water content of leaves, chlorophyll content, plant height, number of grains per plant, grain yield, oil and protein content of soybean. The valuable economic traits in the soybean plant, grain yield, oil and protein amount were improved by $72.23,5.32$ and $10.08 \%$, respectively. Consequently, increased relative water content of leaves and enhanced amount of photosynthetic pigments improved the photosynthetic potential of the plants and stimulated both quantitative and qualitative traits associated with grain yield.

In addition, these traits increased also under the influence of different methanol concentrations, with a maximum at $20 \%$ concentration. The resulting increases in grain yield, oil and protein content were by 19.04, 3.91 and $5.25 \%$, respectively. The interactions between the two treatments was significant and the effect from treatments in the second year of the experiment increased due to favourable weather conditions. Since the overall yield of oil and protein in soybean is very important, and since the yield of oil and protein is obtained through grain yield $\times$ oil and protein content, therefore, magnetic water treatment with an intensity of $8 \mathrm{mT}$ and the use of methanol with a concentration of $20 \%$ achieved the maximum performance regarding oil and protein content. These treatments can thereby be recommended.

\section{References}

Abd-Elrahman S.H., Shalaby O.A. 2017. Response of wheat plants to irrigation with magnetized water under Egyptian soil conditions. Egypt. J. Soil Sci. 57: 477-488.

Alderfasi A.A., Al-Suhaibani N.A., Selim M.M., Al-Hammad B.A.A. 2016. Using magnetic technologies in management of water irrigation programs under arid and semi-arid ecosystem. Adv. Plants Agric. Res. 3: 109-116.

Aliverdi A., Parsa M., Hammami H. 2015. Increased soyabeanrhizobium symbiosis by magnetically treated water. Biol. Agric. Hortic. 31: 167-176

Anand A., Nagarajan Sh., Verma A.P.S., Joshi D.K., Pathak P.C., Bhardwaj J. 2012. Pre-treatment of seeds with static magnetic field ameliorates soil water stress in seedling of maize (Zea mays L.). Indian J. Biochem. Biophys. 49: 63-70.

Asadi Samani M., Pourakbar L., Azimi N. 2013. Magnetic field effects on seed germination and activities of some enzymes in cumin. Life Sci. J. 10: 323-328.

Ashraf M.W. 2014. Magnetic treatment of irrigation water and its effect on water salinity. $2^{\text {nd }}$ International Conference on Food and Agricultural Sciences. IACSIT Press, Singapore. IPCBEE 77: 1-5.

Babaloo F., Majd A., Arbabian S., Sharifnia F., Ghanati F. 2018. The effect of magnetized water on some characteristics of growth and chemical constituent in rice (Oryza sativa L.) var Hashemi. Eurasian J. BioSci. 12: 129-137.

Bai Y.R., Yang P., Su Y.Y., He Z.L., Ti X.N. 2014. Effect of exogenous methanol on glycolate oxidase and photorespiratory intermediates in cotton. J. Exp. Bot. 65: 5331-5338.

Bayat V., Paknejad F., Ardakani M.R., Vazan S., Azizi J., Mafakheri S. 2012. Effect of methanol spraying on physiological characteristics, oil and protein yields of soybean (cv. Williams) under deficit irrigation. Ann. Biol. Res. 3: 871-883.

Bilalis D.J., Katsenios N., Efthimiadou A., Karkanis A., Khah E.M., Mitsis T. 2013. Magnetic field pre-sowing treatment as an organic friendly technique to promote plant growth and chemical elements accumulation in early stages of cotton. Austr. J. Crop Sci. 7: 46-50.

Dixit S, Upadhyay S.K, Singh H, Sidhu O.P, Verma P.C. 2013. Enhanced methanol production in plants provides broad spectrum insect resistance. PLOS One 8: e79664.

Dorokhov Y.L., Sheshukova E.V., Komarova T.V. 2018. Methanol in plant life. Front. Plant Sci. 9: 1623.

Đukić V., Miladinov Z., Dozet G., Cvijanović M., Tatić M., MiladinovićJ., Balešević-Tubić S. 2017. Pulsed electromagnetic field- a cultivation practice used to increase soybean seed germination and yield. Zemdirbyste-Agriculture 104: 345-352.

Efthimiadou A., Katsenios N., Karkanis A., Papastylianou P., Triantafyllidis V., Travlos I., Bilalis D. J. 2014. Effects of 
presowing pulsed electromagnetic treatment of tomato seed on growth, yield, and lycopene content. Sci. World J. 2014: 1-6.

El Sayed H.A.E.S. 2014. Impact of magnetic water irrigation for improve the growth, chemical composition and yield production of broad bean (Vicia faba L.) plant. Am. J. Exp. Agric. 4: 476-496.

Elshokali A.A.M., Abdelbagi A.M. 2014. Impact of magnetized water on elements contents in plants seeds. Int. J. Sci. Res. Innov. Technol. 1: 12-21.

Eşitken A., Turan M. 2004. Alternating magnetic field effects on yield and plant nutrient element composition of strawberry (Fragaria $\times$ ananassa cv. camarosa). Acta Agric. Scand. B Soil Plant Sci. 54: 135-139.

Faver K.L., Gerik T.J. 1996. Foliar-applied methanol effects on cotton (Gossypium hirsutum L.) gas exchange and growth. Field Crops Res. 47: 227-234.

Feibert E.B.G., James S.R., Rykbost K.A., Mitchell A.R., Shock C.C. 1995. Potato yield and quality not changed by foliar-applied methanol. HortScience 30: 494-495.

Galbally I.E., Kirstine W. 2002. The production of methanol by flowering plants and the global cycle of methanol. J. Atmosph. Chem. 43: 195-229.

Gora M.K., Jakhar K.C., Jat H., Kumar P.2018. A review: structured water technology: its effect on productivity of agricultural crops. Int. J. Chem. Stud. 6: 3248-3253.

Jafari Paskiabi M., Safarzadeh Vishekaei M.N., Noorhosseini Niyaki S.A., Farzi M., Aslani A. 2011. Effect of time and foliar spraying by methanol on growth and yield of cowpea (Vigna unguiculata). Middle-East J. Sci. Res. 8: 173-177.

Hemming D.J.B., Criddle R., Hansen L.D. 1995. Effects of methanol on plant respiration. J. Plant Physiol. 146: 193-198.

Hossinzadeh S.R., Ganjeali A., Salami A., Ahmadpour R. 2012. Effects of foliar application of methanol on growth and root characteristics of chickpea (Cicer arietinum L.) under drought stress. Eur. J. Exp. Biol. 2: 1697-1702.

Hozayn M., Abd El-Monem A.A., Abdul Qados A.M.S., Abd ElHameid E.M. 2011. Response of some food crops to irrigation with magnetized water under greenhouse condition. Austr. J. Basic Appl. Sci. 5: 29-36.

Hozayn M., Abdallha M.M., Abd El-Monem, A.A, El-Saady A.A., Darwish M.A. 2016. Applications of magnetic technology in agriculture: A novel tool for improving crop productivity (1): Canola. Afr. J. Agric. Res. 11: 441-449.

Isaac A. E., Hernández A.C., Domínguez P.A., Cruz O.A. 2011. Effect of pre-sowing electromagnetic treatment on seed germination and seedling growth in maize (Zea mays L.). Agron. Colomb. 29: 213-220.

Kobraee S., Shamsi K. 2015. Relationships between oil, protein and dry matter in soybean seed with some of micronutrients fertilization. Res. J. Soil Biol. 7: 56-63.

Li Y., Gupta J., Siyumbbano A.K. 1995. Effect of methanol on soybean photosynthesis and chlorophyll. J. Plant Nutr. 18: 1875-1880.

Liu X., Zhang H., Wang J., Wu X., Ma S., Xu Z., Zhou T., Xu N., Tang X., An B. 2019. Increased $\mathrm{CO}_{2}$ concentrations increasing water use efficiency and improvement PSII function of mulberry seedling leaves under drought stress. J. Plant Interact. 14: 213-223.

Maheshwari B.L., Grewal, H. S. 2009. Magnetic treatment of irrigation water: Its effects on vegetable crop yield and water productivity. Agric. Water Manage. 96: 1229-1236.

Mirakhori M., Paknejad F., Moradi F., Ardakani M.R., Zahedi H., Nazeri, P. 2009. Effect of drought stress and methanol on yield and yield components of soybean max (L 17). Am. J. Biochem. Biotechnol. 5: 162-169.

Moreno-Delafuente A., Viñuela H., Fereres A., Medina P., Trebicki P. 2020. Simultaneous increase in $\mathrm{CO}_{2}$ and temperature alters wheat growth and aphid performance differently depending on virus infection. Insects 11: 459.

Negishi Y., Hashimoto A., Tsushima M., Dobrota C., Yamashitaj M., Nakamura T. 1999. Growth of pea epicotyl in low magnetic field implication for space research. Adv. Space Res. 23: 2029-2032.

Nehbandani A.R., Soltani A., Rahemi-Karizaki A., Dadrasi A., Nourbakhsh F. 2020. Determination of soybean yield gap and potential production in Iran using modelling approach and GIS. J. Integr. Agric. 19: 2-14.

Nonomura A.M., Benson A.A. 1997. Methods and compositions for enhancing carbon fixation in plants. United States Patent, No. 55974.

Nonomura A.M., Benson A.A. 1992. The path of carbon in photosynthesis: Improved crop yields with methanol. Proc. Nat. Acad. Sci. USA 89: 9794-9798.

Radha T.K., Savalgi V.P., Alagawadi A.R. 2009. Effect of methylotrophs on growth and yield of soybean (Glycine max L. Merrill). Karnataka J. Agric. Sci. 22: 118-121.

Rezaiiasl A., Ghasemnezhad A., Shahabi S. 2012. Study the response of cucumber plant to different magnetic fields. $J$. Adv. Labor. Res. Biol. 3: 42-46.

Ritchie S.W., Nguyen H.T., Haloday A.S. 1990. Leaf water content and gas exchange parameters of two wheat genotypes differing in drought resistance. Crop Sci. 30: 105-111.

Sadeghipour O. 2016. The Effect of magnetized water on physiological and agronomic traits of cowpea (Vigna unguiculata L.). Int. J. Res. Chem. Metallurg. Civil Eng. 3: 195198.

Shalatonin V. 2017. Effect of unipolar magnetic field on macroscopic properties of distilled water. Int. J. Pharma Med. Biol. Sci. 6: 89-93.

Singh A., Kumar S., Akula S., Lawrence D.M., Lombardozzi D.L. 2020. Plant growth nullifies the effect of increased water use efficiency on streamflow under elevated $\mathrm{CO}_{2}$ in the southeastern United States. Geophys. Res. Lett. doi:10.1029/2019gl086940.

Surendran U., Sandeep O., Joseph E.J. 2016. The impacts of magnetic treatment of irrigation water on plant, water and soil characteristics. Agric. Water Manage. 178: 21-29.

Teixeira da Silva J.A., Dobránszki J. 2014. Impact of magnetic water on plant growth. Environ. Exp. Biol. 12: 137-142.

Thompson M., Gamage D., Hirotsu N., Martin A., Seneweera S. 2017. Effects of elevated carbon dioxide on photosynthesis and carbon partitioning: A perspective on root sugar sensing and hormonal crosstalk. Front. Physiol. 8: 578.

Yusuf K.O., Ogunlela A.O. 2017. Effect of magnetic treatment of water on evapotranspiration of tomato. Arid Zone J. Eng. Technol. Environ. 13: 86-96.

Zbieć I., Karczmarczyk S., Podsiadł O. 2003. Response of some cultivated plants to methanol as compared to supplemental irrigation. Electr. J. Polish Agric. Univ. 6: 1-7. 